\title{
EFEKTIFITAS PEMBERIAN LATIHAN FISIK : SENAM DIABETES TERHADAP PENGENDALIAN KADAR GULA DARAH PADA PENDERITA DIABETES MELITUS
}

\author{
${ }^{1}$ Dwi Christina Rahayuningrum, ${ }^{2}$ Risda Yenni \\ ${ }^{1}$ Syedza Saintika Padang. Jl. Prof. Dr Hamka No.228. \\ E-mail:noeninksweet@gmail.com \\ ${ }^{2}$ Syedza Saintika Padang. Jl. Prof. Dr Hamka No.228. \\ E-mail:noeninksweet@gmail.com
}

\begin{abstract}
ABSTRAK
Diabetes mellitus merupakan salah satu penyakit tidak menular yang menyita banyak perhatian. Berbagai upaya pengobatan yang dapat dilakukan untuk mengatasi peningkatan jumlah penderita diabetes mellitus. Salah satunya dengan pemberia latihan fisik yaitu senam diabetes. Senam diabetes bermanfaat dalam mengontrol kadar gula darah, menghambat serta memperbaiki faktor resiko penyakit kardiovaskuler yang merupakan akibat lanjut dari diabetes mellitus, mencegah Dm secara dini, serta dapat menurunkan kebutuhan pemakaian obat oral dan insulin. Tujuan penelitian ini adalah untuk Mengetahui Efektifitas Pemberian Latihan Fisik: Senam Diabetes terhadap Pengendalian Kadar Gula Darah pada Penderita Diabetes Melitus di Wilayah Kerja Puskesmas Paraman Ampalu Kabupaten Pasaman Barat Tahun 2017. Jenis penelitian ini adalah penelitian quasy experiment. Teknik pengambilan sampel adalah purposive sampling, yaitu 30 orang dengan 15 kasus dan 15 kontrol. Hasil uji statistik chi square menunjukkan Senam Diabetes efektif terhadap pengendalian kadar gula darah pada penderita Diabetes Melitus dengan $(p=0.018$ ). Berdasarkan penelitian ini disarankan bagi Puskesmas untuk dapat melakukan upaya pengendalian kadar gula darah pada penderita Diabetes Melitus dengan teknik non farmakologis salah satunya dengan senam diabetes
\end{abstract}

\section{Kata Kunci ：Diabetes Melitus, Senam Diabetes Melitus, Kadar Gula Darah}

\begin{abstract}
Diabetes mellitus is one of the non-communicable diseases that take a lot of attention. Various treatment efforts that can be done to overcome the increasing number of people with diabetes mellitus. One of them with physical exercise regulator that is diabetes gymnastics. Gymnastics diabetes is beneficial in controlling blood sugar levels, inhibiting and improving cardiovascular disease risk factors that are a further consequence of diabetes mellitus, preventing early Dm, and may decrease the need for oral and insulin drug use. The purpose of this study is to Know the Effectiveness of Physical Exercise: Diabetes Gymnastic on Blood Sugar Level Control in Diabetes Mellitus Patients in the Working Area of Paraman Ampalu Puskes Pasaman Barat Regency 2017. This research type is quasy experiment research. The sampling technique was purposive sampling, ie 30 people with 15 cases and 15 controls. The result of chi square statistic test showed that Diabetes Gymnastic is effective against blood sugar level control in Diabetes Mellitus patient $(p=0.018)$. Based on this research is suggested for Puskesmas to be able to make effort to control blood sugar level in patient of Diabetes Mellitus with non pharmacological technique one of them with diabetes gymnastics.
\end{abstract}

Keywords: $\quad$ Diabetes Mellitus, Gymnastics Diabetes Mellitus, Blood Sugar Level 


\section{PENDAHULUAN}

Salah satu penyakit tidak menular yang menyita banyak perhatian adalah Diabetes Mellitus atau DM (Kemenkes, 2013). Diabetes Melitus (DM) merupakan sekelompok kelainan heterogen yang ditandai oleh kenaikan kadar glukosa dalam darah atau hiperglikemia (Smeltzer, 2013). Berdasarkan data International Diabetes Federation (IDF) pada tahun 2013, terdapat 382 juta orang yang hidup dengan DM di dunia. Pada tahun 2035, jumlah tersebut diperkirakan akan meningkat menjadi 592 juta (Kemenkes, 2014). DM menduduki peringkat ke-6 sebagai penyebab kematian. Sekitar 1,3 juta orang meninggal akibat diabetes dan $4 \%$ meninggal sebelum usia 70 tahun. Indonesia merupakan Negara urutan ke7 dengan prevalensi diabetes tertinggi di bawah China, India, USA, Brazil, Rusia, dan Mexico.

Global status report on non communicable diseases tahun 2014 yang dikeluarkan oleh World Health Organization (WHO) menyatakan bahwa prevalensi DM di seluruh dunia diperkirakan sebesar 9\%. Proporsi kematian akibat penyakit DM dari seluruh kematian akibat penyakit tidak menular adalah sebesar 4\%. Kematian akibat DM terjadi pada negara dengan pendapatan rendah dan menengah dengan proporsi sebesar $80 \%$. Pada Tahun 2030 diperkirakan DM menempati urutan ke-7 penyebab kematian di dunia.

Badan kesehatan dunia (WHO) memperkirakan pada tahun 2030 penderita diabetes melitus di Indonesia sebanyak 21, 3 juta jiwa. Kondisi ini membuat Indonesia menduduki peringkat keempat setelah Amerika Serikat, China, dan India. Terdapat 347 juta jiwa di dunia menderita diabetes melitus, pada tahun 2012 diperkirakan 1,5 juta jiwa meninggal dunia disebabkan oleh diabetes melitus dan kurang lebih $80 \%$ dari kematian tersebut terjadi pada negara yang berpenghasilan menengah ke bawah atau negara yang berkembang (WHO, 2014). Laporan dari Badan Penelitian dan Pengembangan Kesehatan Kementrian Kesehatan (RISKESDAS) tahun 2013 menyebutkan terjadi peningkatan prevalensi pada penderita diabetes melitus di daerah urban
Indonesia untuk usia diatas 15 tahun sebesar $5,7 \%$. Prevalensi terkecil terdapat di propinsi Papua sebesar $1,7 \%$, dan terbesar di propinsi Maluku Utara dan Kalimantan Barat yang mencapai $11,1 \%$, sedangkan prevalensi Toleransi Glukosa Terganggu (TGT), berkisar antara 4,0\% di propinsi Jambi sampai 21,8\% di propinsi Papua Barat.

Peningkatan prevalensi penyakit diabetes melitus ini disebabkan oleh pertumbuhan masyarakat yang semakin tinggi, peningkatan obesitas, faktor stres, diet dan pola makan yang tidak sehat, dan gaya hidup yang sekunder. Percepatan naiknya prevalensi penderita diabetes melitus dapat dipicu oleh pola makan yang salah, dimana pada saat sekarang banyak masyarakat yang kurang menyediakan makanan berserat, banyak konsumsi makanan yang mengandung kolesterol, lemak jenuh, dan natrium, diperparah lagi dengan seringnya mengkonsumsi makanan dan minuman yang kaya akan gula (Qurratueni, 2009). Pola makan dan gaya hidup yang tidak sehat ini dapat memunculkan berbagai komplikasi akut maupun kronis pada penderita diabetes melitus jika tidak ditangani secara baik dan untuk mencegah terjadinya komplikasi, diperlukan adanya pengelolaan / penatalaksanaan diabetes melitus.

DM memiliki dampak sangat berbahaya karena dapat menimbulkan komplikasi. Komplikasi diabetes terjadi pada semua organ tubuh dengan penyebab kematian $50 \%$ akibat penyakit jantung koroner dan $30 \%$ akibat gagal jantung. Selain kematian, diabetes juga menyebabkan kecacatan, sebanyak $30 \%$ penderita diabetes mellitus mengalami kebutaan akibat komplikasi retinopati dan $10 \%$ menjalani amputasi tungkai kaki (Medicastore, 2007). Oleh karena itu diperlukan usaha pengendalian yang harus dilakukan oleh penderita DM. Dalam mengendalikan diabetes mellitus diperlukan empat pilar penyangga yang mendukung, yaitu edukasi, diet, olahraga, dan obat (Novitasari, 2012). Banyak penderita DM yang lebih fokus dan hanya mengutamakan pada penanganan diet, dan mengkonsumsi obat-obatan. Namun penangaanan diet yang teratur belum menjamin akan terkontrolnya kadar gula darah, akan tetapi hal ini harus diseimbangi dengan latihan fisik yang sesuai (Sinaga, 2012). 
Penelitian terbaru memperlihatkan efek menguntungkan dari latihan jasmani yang teratur terhadap metabolisme karbohidrat dan sensifitas insulin. efek dari latihan jasmani dapat dipertahankan minimal 5 tahun (American Diabetes Association, 2007). Aktifitas atau pergerakan tubuh sering diabaikan oleh setiap penderita DM, hal ini dapat disebabkan oleh berbagai faktor seperti keterbatasan waktu untuk melakukan olahraga karena pekerjaan, usia yang tidak memungkinkan, dan minat yang kurang untuk melakukan aktifitas, serta kurangnya pengetahuan akan pentingnya olahraga (Sinaga, 2012). Program olahraga yang digabung dengan penurunan berat badan telah memperlihatkan peningkatan sensitivitas insulin dan menurunkan kebutuhan terhadap intervensi farmakologi (Corwin, 2009). Salah satu olahraga yang bisa dilakukan pada penderita DM adalah senam diabetes mellitus. Senam diabetes mellitus yang direkomendasikan bagi orang dewasa adalah 30 menit minimal 3-4 kali dalam seminggu sedangkan bagi anak-anak dan remaja adalah 60 menit (Darwin, 2013).

Terapi untuk mengontrol serta menurunkan kadar gula darah diharapkan setiap minggunya melakukan latihan jasmani secara rutin. Latihan jasmani dibagi menjadi 3-4 kali tiap minggu selama 30 sampai 45 menit. Latihan jasmani yang terprogram dapat menurunkan kadar gula darah memperbaiki kepekaan dan menambah jumlah reseptor insulin, dapat menurunkan resistensi insulin. Latihan jasmani yang dianjurkan untuk menurunkaan kadar gula darah berupa latihan jasmani yang bersifat aerobik seperti: senam, jalan kaki, bersepeda santai, jogging, dan berenang. Latihan jasmani sebaiknya disesuaikan dengan umur dan status kesegaran jasmani (Perkeni, 2011).

Senam diabetes merupakan senam low impact dan ritmis yang telah dilaksanakan sejak tahun 1997 di klub-klub diabetes di Indonesia. Senam diabetes efektif dapat menurunkan kadar gula darah dan memperlancar peredaran darah perifer (Santoso, 2006). Senam diorekomendasikan dilakukan dengan intensitas sedang, durasi 30 menit dengan frekuensi 3-5 kali per-minggu dan tidak lebih dari 2 hari berturut-turut tidak melakukan senam (ADA, 2006). Senam diabetes ditujukan khusus kepada penderita DM dimana gerakan menyenangkan dan tidak membosankan serta dapat diikuti oleh semua kelompok umur (Rachmawati, 2010).

Olahraga dapat mengatur gula darah melalui tiga mekanisme yaitu perangsangan akut transport gula otot, penguatan akut kerja insulin dan up-regulation jalur jangka panjang insulin signal. Perbaikan kepekaan insulin merupakan dampak dari afinitas reseptor insulin, pengendalian gula mengarah pada penundaan penebalan membran basal pembuluh darah (Giri, 2013). Glukosa darah puasa adalah glukosa darah yang diperiksa setelah pasien melakukan puasa selama minimal 8 jam. Aktifitas fisik meliputi berbagai intensitas dan volume dapat meminimalkan resistansi insulin (meningkatkan sensitivitas insulin) sehingga glukosa darah dapat menurun. Berdasarkan jurnal Afriza (2013) tentang pengaruh senam diabetes terhadap kadar glukosa darah pada penderita diabetes mellitus, didapatkan hasil rata-rata kadar glukosa darah sebelum senam adalah $231.86 \mathrm{mg} / \mathrm{dl}$ dan ratarata kadar glukosa darah sesudah dilakukan senam diabetes adalah $226.93 \mathrm{mg} / \mathrm{dl}$ (Afriza, 2013).

Hasil penelitian yang telah dilakukan oleh Ocbrivianita Mulyaningtyas Utomo, et al tahun 2012, terdapat perbedaan kadar gula darah sewaktu sebelum dan sesudah intervensi senam diabetes pada kelompok senam. Penurunan rata-rata gula darah pada kelompok senam 2,3 kali lebih besar daripada kelompok tidak senam. Menurut penelitian Witriyani (2015) tentang Efektifitas senam Diabetes Melitus dalam menurunkan kadar gula darah pada penderita Diabetes Melitus di Wilayah Kerja Puskesmas Kayumas, dimana Hasil uji Paired Sample T-Test pada kelompok kontrol didapatkan nilai $\mathrm{p}=0,088 \quad(\mathrm{p}>0,05)$, dimana tidak terdapat penurunan kadar gula darah pada kelompok kontrol. Sedangkan hasil uji Paired Sample T-Test pada kelompok intervensi didapatkan nilai $\mathrm{p}=0,000 \quad(\mathrm{p}<0,05)$, terdapat penurunan kadar gula darah pada kelompok perlakuan maka HO ditolak dan Ha diterima sehingga dapat disimpulkan bahwa senam diabetes mellitus efektif dalam menurunkan kadar gula darah pada penderita Diabetes Mellitus di Wilayah kerja Puskesmas Kayumas.

Berdasarkan data rekapan register kematian penyakit tidak menular di Kabupaten 
Volume 2 Nomor 1 P-ISSN : 2597-8594

Pasaman pada tahun 2015, terdapat 22 orang meninggal karena Diabetes Melitus. Total kunjungan pasien Diabetes Melitus adalah 1894 orang dan kasus baru sebanyak 311 orang (Dinkes Pasaman Barat, 2015). Pada tahun 2016 terjadi peningkatan yaitu 1907 orang dan kasus baru sebanyak 331 orang (Dinkes Pasaman Barat, 2016).

Hasil survei data di Puskesmas Paraman Ampalu pada bulan Januari Desember 2015, didapatkan data bahwa terdapat 35 penderita Diabetes Melitus. Sementara itu pada tahun 2016 terdapat 121 penderita Diabetes Melitus, dan pada bulan Januari- Mei tahun 2017 terdapat 248 pasien. Berdasarkan hasil wawancara yang dilakukan peneliti terhadap 10 orang responden, 6 orang penderita Diabetes Melitus rutin mengkonsumsi obat untuk mengendalikan kadar gula darahnya, dan melakukan olahraga senam diabetes mellitus dengan gerakan senam tidak sesuai waktu yang ditentukan. Sementara itu 4 orang penderita Diabetes Melitus tidak bisa mengikuti gerakan senam diabetes.

\section{METODE PENELITIAN}

Jenis penelitian yang dilakukan adalah penelitian quasy experiment dengan desain penelitian yang digunakan adalah pretestposttest design dengan case control. Penelitian dilaksanakan di Wilayah Kerja Puskesmas Paraman Ampalu Kabupaten Pasaman Barat pada bulan September Tahun 2017. Populasi dalam penelitian ini adalah semua penderita DM yang berada di Wilayah Kerja Puskesmas Paraman Ampalu Kabupaten Pasaman Barat pada bulan Januari - Mei Tahun 2017 dengan jumlah pasien 248 orang. Sampel pada penelitian ini sebanyak 30 orang dengan 15 orang kasus dan 15 orang control dengan teknik pengambilan sampel purposive sampling dengan kriteria pasien DM yang tidak diet teratur, Penderita DM dengan GD $<250 \mathrm{~g} / \mathrm{dl}$, Penderita Dm yang tidak menggunakan terapi obat.

\section{HASIL}

1. Analisis Univariat

a. Rata- Rata Kadar Gula Darah pada Penderita Diabetes Melitus sebelum dilakukan intervensi senam diabetes

Tabel 1. Distribusi Responden Berdasarkan Kadar Gula Darah pada Penderita Diabetes Melitus sebelum dilakukan intervensi senam diabetes di Wilayah Kerja Puskesmas Paraman Ampalu Kabupaten Pasaman Barat Tahun 2017

\begin{tabular}{cccc}
\hline Variabel & Mean & $\begin{array}{c}\text { Standar } \\
\text { Deviasi (SD) }\end{array}$ & $\begin{array}{c}\text { Min - } \\
\text { Maks }\end{array}$ \\
\hline GD Pretest Pasien Kasus & 212.20 & 25.476 & $164-247$ \\
\hline GD Pretest Pasien Kontrol & 265.20 & 54.118 & $192-362$ \\
\hline
\end{tabular}

Berdasarkan Tabel 1. menunjukkan bahwa ratarata gula darah pada responden dengan kasus (pretest) 212.20 dengan standar deviasi 25.476, gula darah tertinggi adalah 247 dan terendah
164. Sementara itu rata-rata gula darah pada responden dengan kontrol (pretest) 265.20 dengan standar deviasi 54.118, gula darah tertinggi adalah 362 dan terendah 192.

b. Rata- Rata Kadar Gula Darah pada Penderita Diabetes Melitus setelah dilakukan intervensi senam diabetes

Tabel 2. Distribusi Responden Berdasarkan Rata- Rata Kadar Gula Darah pada Penderita Diabetes Melitus setelah dilakukan intervensi senam diabetes di Wilayah Kerja Puskesmas Paraman Ampalu Kabupaten Pasaman Barat Tahun 2017 


\begin{tabular}{cccc}
\hline Variabel & Mean & $\begin{array}{c}\text { Standar } \\
\text { Deviasi (SD) }\end{array}$ & $\begin{array}{c}\text { Min - } \\
\text { Maks }\end{array}$ \\
\hline GD Posttest Pasien Kasus & 190.80 & 35.688 & $126-246$ \\
\hline GD Posttest Pasien Kontrol & 269.00 & 49.522 & $197-347$ \\
\hline
\end{tabular}

Berdasarkan Tabel 2. menunjukkan bahwa ratarata gula darah pada responden dengan kasus (posttest) 190.80 dengan standar deviasi 190.80, gula darah tertinggi adalah 246 dan terendah 126 . Sementara itu rata-rata gula darah pada responden dengan kontrol (posttest) 269.00 dengan standar deviasi 49.522, gula darah tertinggi adalah 347 dan terendah 197.

\section{Analisis Bivariat}

a. Efektifitas Pemberian Latihan Fisik : Senam Diabetes terhadap Pengendalian Kadar Gula Darah pada Penderita Diabetes Melitus di Wilayah Kerja Puskesmas Paraman Ampalu Kabupaten Pasaman Barat Tahun 2017

Tabel 3. Efektifitas Pemberian Latihan Fisik : Senam Diabetes terhadap Pengendalian Kadar Gula Darah pada Penderita Diabetes Melitus di Wilayah Kerja Puskesmas Paraman Ampalu Kabupaten Pasaman Barat Tahun 2017

\begin{tabular}{|c|c|c|c|c|c|c|c|}
\hline Variabel & $\begin{array}{c}\text { Sebelum } \\
\text { Senam }\end{array}$ & $\begin{array}{l}\text { Sesudah } \\
\text { Senam }\end{array}$ & $\begin{array}{c}\text { Mean } \\
\text { Differen } \\
\text { ces }\end{array}$ & $\begin{array}{c}\text { Std. } \\
\text { Deviasi } \\
\text { (SD) }\end{array}$ & $\begin{array}{l}\text { Std. } \\
\text { Error } \\
\text { Mean }\end{array}$ & $\begin{array}{c}95 \% \\
\text { CI }\end{array}$ & $\begin{array}{c}P \\
\text { Value }\end{array}$ \\
\hline & Mean & Mean & & & & & \\
\hline $\begin{array}{l}\text { GD Pasien } \\
\text { Kasus }\end{array}$ & 212.20 & 190.80 & 21.400 & 30.933 & 7.987 & $\begin{array}{l}4.270- \\
38.530\end{array}$ & 0,018 \\
\hline $\begin{array}{l}\text { GD Pasien } \\
\text { Kontrol }\end{array}$ & 265.20 & 269.00 & -3.800 & 25.157 & $6 . .496$ & $\begin{array}{l}-17.732 \\
-10.123\end{array}$ & 0,568 \\
\hline
\end{tabular}


Berdasarkan Tabel 3. menunjukkan bahwa perbedaan rata-rata gula darah pada responden kasus adalah 21.400 dengan standar deviasi 30.933. Hasil uji statistik didapatkan p Value 0,018 berarti ada perbedaan antara gula darah sebelum dan sesudah dilakukan senam diabetes. Sementara itu, perbedaan rata-rata gula darah responden kontrol adalah -3.800 dengan standar deviasi 21.157. Hasil uji statistik didapatkan p Value 0,568 berarti tidak ada perbedaan antara gula darah sebelum dan sesudah dilakukan senam diabetes. Dapat disimpulkan bahwa Ho ditolak dan Ha diterima yang artinya senam diabetes efektif terhadap pengendalian kadar gula darah pada penderita Diabetes Melitus di Wilayah Kerja Puskesmas Paraman Ampalu Kabupaten Pasaman Barat Tahun 2017.

\section{PEMBAHASAN}

\section{Analisis Univariat}

a. Distribusi Responden Berdasarkan Rata- Rata Kadar Gula Darah pada Penderita Diabetes Melitus sebelum dilakukan intervensi senam diabetes di Wilayah Kerja Puskesmas Paraman Ampalu Tahun 2017

Hasil analisis distribusi frekuensi responden berdasarkan tabel 1 menunjukkan bahwa rata-rata gula darah pada responden dengan kasus (pretest) 212.20 dengan standar deviasi 25.476, gula darah tertinggi adalah 247 dan terendah 164 . Sementara itu rata-rata gula darah pada responden dengan kontrol (pretest) 265.20 dengan standar deviasi 54.118, gula darah tertinggi adalah 362 dan terendah 192.

Penelitian ini sejalan dengan penelitian Afriza (2015) tentang pengaruh senam diabetes terhadap kadar glukosa darah pada penderita diabetes mellitus di Puskesmas Lapai Kecamatan Nanggalo Kota Padang, dimana dari hasil penelitian berdasarkan hasil data tes awal kadar glukosa darah dari 28 orang responden di Puskesmas Lapai Kecamatan Nanggalo Kota Padang, sebelum diberikan perlakuan dengan senam diabetes diperoleh nilai rata-rata (mean) adalah 231,86 $\mathrm{mg} / \mathrm{dl}$, standar deviasi adalah 56,35 dan nilai tertinggi adalah $372 \mathrm{mg} / \mathrm{dl}$ dan skor terendah yaitu 167 $\mathrm{mg} / \mathrm{dl}$.

Kadar gula darah yang tinggi tersebut dikarenakan terjadinya hiperglikemia akibat gangguan resistensi insulin dan gangguan sekresi insulin. Peningkatan kadar gula darah ini juga disebabkan karena responden tidak mampu untuk mengontrol atau menurunkan kadar gula darahnya agar tetap stabil. Faktor pencetus peningkatan kadar gula darah tersebut akibat gaya hidup dan kurangnya aktivitas (Indriyani, 2007).

Menurut analisa peneliti, sebagian besar responden memilki kadar gula darah tidak normal, hal ini ditunjukkan pada tabel 4.1 dimana rata-rata gula darah pada responden dengan kasus (pretest) 212.20 dengan standar deviasi 25.476, gula darah tertinggi adalah 247 dan terendah 164. Sementara itu rata-rata gula darah pada responden dengan kontrol (pretest) 265.20 dengan standar deviasi 54.118, gula darah tertinggi adalah 362 dan terendah 192. Hal ini disebabkan karena responden tidak melakukan aktifitas fisik berupa senam diabetes dalam pengendalian kadar gula darah.

b. Distribusi Responden Berdasarkan Rata- Rata Kadar Gula Darah pada Penderita Diabetes Melitus setelah dilakukan intervensi senam diabetes di Puskesmas Paraman Ampalu Tahun 2017

Hasil analisis distribusi frekuensi responden berdasarkan tabel 2 menunjukkan bahwa rata-rata gula darah pada responden dengan kasus (posttest) 190.80 dengan standar deviasi 190.80, gula darah tertinggi adalah 246 dan terendah 126. Sementara itu rata-rata gula darah pada responden dengan kontrol (posttest) 269.00 dengan standar deviasi 49.522, gula darah tertinggi adalah 347 dan terendah 197.

Penelitian ini sejalan dengan penelitian Erlina (2012) tentang pengaruh senam diabetes terhadap kadar glukosa darah pasien Dm Tipe 2 di RSU Unit Swadana Daerah Kabupaten Sumedang, dimana dari hasil penelitian rerata kadar glukosa darah sebelum intervensi lebih rendah dibandingkan rerata kadar glukosa darah sesudah intervensi. Rerata kadar glukosa darah responden sebelum intervensi sebesar 192,60 mg/dl dan rerata kadar glukosa darah sesudah intervensi turun menjadi $159,73 \mathrm{mg} / \mathrm{dl}$. Penurunan rerata kadar glukosa darah sesudah intervensi sebesar 38,97 mg/dl dibandingkan sebelum intervensi.

Penelitian ini sesuai dengan teori Chaveau dan Kaufman dalam Ilyas (2007) yang menyatakan latihan jasmani secara langsung dapat menyebabkan terjadinya peningkatan pemakaian glukosa oleh otot yang aktif. 
Latihan jasmani yang teratur menyebabkan permeabilitas membran meningkat pada otot yang berkontraksi sehingga saat latihan resistensi insulin berkurang dan sensitivitas insulin meningkat.

Menurut analisa peneliti, dapat disimpulkan bahwa, setelah dilakukan intervensi senam diabetes yang mulai diberikan hari pertama selama $3 \mathrm{x}$ dalam seminggu kepada penderita DM, memberikan efek yang bermakna terhadap penurunan gula darah pada responden. Hal ini dapat dilihat pada tabel 2 dimana rata-rata gula darah pada responden dengan kasus (posttest) terjadi penurunan kadar gula darah menjadi 190,80 dengan rata - rata penurunan sebesar 21,40 dimana gula darah tertinggi adalah 246 dan terendah 126. Sementara itu pada responden kontrol yang tidak melakukan intervensi Senam Diabetes tidak terjadi penurunan gula darahnya malah rata - rata naik menjadi 269,00.

\section{Analisa Bivariat \\ Efektifitas Pemberian Latihan Fisik : Senam Diabetes terhadap Pengendalian Kadar Gula Darah pada Penderita Diabetes Melitus di Wilayah Kerja Puskesmas Paraman Ampalu Kabupaten Pasaman Barat Tahun 2017}

Hasil penelitian ini menunjukkan bahwa perbedaan rata-rata gula darah pada responden kasus adalah 21.400 dengan standar deviasi 30.933. Hasil uji statistik didapatkan $\mathrm{p}$ value 0,018 berarti ada perbedaan antara gula darah sebelum dan sesudah dilakukan senam diabetes. Sementara itu, perbedaan rata-rata gula darah responden kontrol adalah -3.800 dengan standar deviasi 21.157. Hasil uji statistik didapatkan $\mathrm{p}$ value 0,568 berarti tidak ada perbedaan antara gula darah sebelum dan sesudah dilakukan senam diabetes. Dapat disimpulkan bahwa Ho ditolak dan Ha diterima yang artinya senam diabetes efektif terhadap pengendalian kadar gula darah pada penderita Diabetes Melitus di Wilayah Kerja Puskesmas Paraman Ampalu Kabupaten Pasaman Barat Tahun 2017.

Penelitian ini sejalan dengan penelitian yang dilakukan oleh Witriyani (2015) tentang efektifitas senam diabetes mellitus dalam menurunkan kadar gula darah pada penderita diabetes mellitus di Wilayah Kerja Puskesmas Kayumas, dimana Penelitiian ini menggunakan metode penelitian quasy eksperiment dengan pretest-posttest. Sampel penelitian sebanyak 32 dengan teknik Purposive Sampling. Analisa data dilakukan dengan menggunakan uji Paired Sample T Test. Hasil uji Paired Sample T-Test pada kelompok kontrol didapatkan nilai $\mathrm{p}=0,088 \quad(\mathrm{p}>0,05)$, dimana tidak terdapat penurunan kadar gula darah pada kelompok kontrol. Sedangkan hasil uji Paired Sample TTest pada kelompok intervensi didapatkan nilai $\mathrm{p}=0,000 \quad(\mathrm{p}<0,05)$, terdapat penurunan kadar gula darah pada kelompok perlakuan maka $\mathrm{H} 0$ ditolak dan $\mathrm{Ha}$ diterima sehingga dapat disimpulkan bahwa senam diabetes mellitus efektif dalam menurunkan kadar gula darah pada penderita Diabetes Mellitus di wilayah kerja Puskesmas Kayumas.

Hasil penelitian ini mendukung penelitian Kriska (2007) yang menyimpulkan individu yang lebih aktif memiliki kadar glukosa darah yang lebih rendah dibanding yang tidak aktif. Senam diabetes mellitus memiliki peran utama dalam pengaturan kadar glukosa darah. Pada saat berolahraga, keadaan permiabilitas membran terhadap glukosa meningkat pada otot yang berkontraksi sehingga resistensi insulin berkurang, dengan kata lain sensitivitas insulin meningkat (Widianti, 2010). Penelitian juga sesuai dengan pendapat Yunir dalam Sudoyo (2006) yang menyatakan kegiatan fisik dinamik yang melibatkan otot-otot utama akan menyebabkan permeabilitas meningkat pada otot yang berkontraksi, sehingga saat latihan reseptor insulin akan lebih banyak dan lebih peka. Kepekaan reseptor insulin dapat berlangsung 12-24 jam setelah senam, yang menyebabkan glukosa darah dapat kembali normal (Ilyas dalam Soegondo, 2006).

Frekuensi senam dalam penelitian ini memenuhi standar minimal yaitu 3 kali perminggu dengan teratur. Hal ini sesuai dengan prinsip senam diabetes yang menyatakan untuk mencapai hasil yang optimal latihan harus dilakukan teratur 3-5 kali perminggu dan tidak lebih 2 hari berurutan tanpa latihan (American Diabetes Association, 2004). Penurunan kadar glukosa darah responden juga dipengaruhi oleh tercapainya intensitas yang baik selama intervensi. Intensitas senam dapat dinilai dari target nadi, tekanan darah dan kadar glukosa darah sebelum dan sesudah senam. Rerata target nadi responden sesudah latihan mencapai $63,53 \%$ 
MHR dan rerata tekanan darah sistolik responden sesudah latihan 160,67 $\mathrm{mmHg}$. Kondisi ini sesuai dengan konsep yang menyatakan latihan akan bermanfaat jika mencapai kondisi optimal yaitu tekanan darah setelah latihan tidak lebih dari $180 \mathrm{mmHg}$ dan denyut nadi mencapai 60-79\% MHR. Jika kurang dari $60 \%$ latihan kurang bermanfaat dan jika lebih dari 79\% akan membahayakan kesehatan pasien (Santoso, 2006).

Menurut asumsi peneliti, latihan jasmani senam diabetes mellitus yang diberikan oleh peneliti selama 2 minggu dengan frekuensi 3 kali dalam 1 minggu terbukti dapat menurunkan kadar gula darah responden. Hal ini dapat dilihat dari hasil penelitian, dimana rata-rata gula darah sebelum dilakukan intervensi 212.20 dan setelah dilakukan intervensi terjadi penurunan kadar gula darah menjadi 190,80 dengan rata - rata penurunan sebesar 21,40. Dalam latihan ini diusahakan responden mampu mencapai THR (Target Heart Rate) agar tercapai hasil yang optimal. Menurut peneliti, perilaku olahraga penderita diabetes mellitus berpengaruh terhadap kadar gula darah. Hal ini dibuktikan dengan hasil uji statistik dimana senam diabetes mellitus efektif dalam mengendalikan kadar gula darah dengan hasil $\mathrm{p}$ value $0,018(\mathrm{p} \leq 0.05)$.

\section{KESIMPULAN}

Dari hasil penelitian dapat disimpulkan bahwa terdapat penurunan gula darah pada responden yang melakukan senam diabetes. Senam diabetes efektif terhadap pengendalian kadar gula darah pada penderita Diabetes Melitus di Wilayah Kerja Puskesmas Paraman Ampalu Kabupaten Pasaman Barat Tahun 2017. Senam diabetes merupakan salah satu teknik nonfarmakologi yang dapat mengontrol kadar gula darah. Senam diabetes memiliki manfaat dalam mengontrol gula darah, faktor resiko peyakit kardiovaskuler yang merupakan akibat lanjut dari DM dari dihambat atau diperbaiki, selain itu pencegah terjadinya DM secara dini. Dengan melakukan senam diabetes Kebutuhan pemakaian obat oral dan insulin berkurang. Senam diabetes dilakukan oleh responden, yang mana dalam pelaksanaannya dapat dilakukan dirumah, efisien dan tidak membutuhkan biaya. Peneliti menyarankan Puskesmas Paraman Ampalu untuk dapat melakukan upaya pengendalian kadar gula darah pada penderita Diabetes Melitus dengan teknik non farmakologis salah satunya dengan senam diabetes. Karena senam diabetes merupakan salah satu teknik nonfarmakologis yang sangat mudah dilakukan dan sangat efisien. Sehingga efek lanjut dari penggunaan obat yang lama tidak dapat ditemukan lagi.

\section{DAFTAR PUSTAKA}

ADA. 2006. Diabetes Care. http//: care. diabetes. journal. org/ content/27/sppll/s5full. Diakses pada tanggal 20 Mei 2017

Arisman. 2011. Obesitas, Diabetes Melitus, dan Dislipidemia. Jakarta: EGC

Black \& Hawks. 2009. Using Self Management skill to Adhere to Healthy Life Style Behavior. Diakses dari http://highered.mcgraw_hill.com/pada 16 Mei 2017

Brunner \& Suddarth. 2012. Buku Ajar Keperawatan Medikal Bedah. Jakarta: EGC

Bustan. 2007. Epidemiologi Penyakit tidak Menular. Jakarta: Rineka Cipta

Corwin. 2009. Buku Saku Patofisiologi Edisi Revisi 3. Jakarta: EGC

Darwin. 2013. Menikmati Gula tanpa Rasa Takut. Yogyakarta: Sinar Ilmu

Dinkes Kab Pasaman Barat. 2016. Laporan Kumpulan Penyakit Kab Pasaman Barat. Dinkes Kabupaten Pasaman Barat.

Giri. 2013. Ilmu Kesehatan Olahraga. PT Remaja Rosdakarya

Hasdianah. 2013. Mengenal Diabetes Melitus. Yogyakarta : Nuha Medika

Kemenkes Kesehatan RI. 2014. Waspada Diabetes Mellitus Eat Well Live Well. Situasi dan Analisa Diabetes. Jakarta: Kemenkes RI

Nabil. 2009. Panduan Hidup Sehat: Mencegah dan Mengobati Diabetes Melitus. Yogyakarta: Aulia Publising 
Notoadmodjo, S. 2012. Metode Penelitian Kesehatan . Jakarta : Rineka Cipta

Perkeni. 2011. Konsensus Pengelolaan dan Pencegahan Diabetes Mellitus Tipe 2 di Indonesia Tahun 2011. Diakses pada tanggal 22 April 2017 dari http.www.perkeni.net.

Rachmawati. 2010. Pengaruh Dukungan Keluarga terhadap Kualitas Hidup Pasien Diabetes Melitus Tipe II. Jurnal Keperawatan. Bandung: Universitas Padjajaran

Riskesdas. 2013. Badan Penelitian dan Pengembangan Kesehatan. Kemenkes RI

Saintika, S. 2016. Panduan penulisan proposal atau skripsi. Syedza Saintika Padang

Santoso. 2006. Senam Diabetes Indonesia seri 3. Jakarta: Persatuan Diabetes Indonesia

Sinaga. 2012. Pengaruh Senam Diabetes Melitus terhadap Kadar Glukosa Darah pada Penderita Diabetes Melitus di Wilayah Kerja Puskesmas Darussalam Medan. Jurnal Mutiara Ners, Volume 1, No 7 Januari 2012. Http://sari-mutiara.ac.id/. Diakses tanggal 20 Mei 2017.

Smeltzer. 20113. Buku Ajar Keperawatan Medikal Bedah. Jakarta : EGC

Soegondo, S. 2011. Diagnosis dan Klasifikasi Diabetes Mellitus Terkini. Jakarta : FKUI

Sudoyo. 2009. Buku Ajar Ilmu Penyakit Dalam Jilid II edisi $V$. Jakarta : Interna Publishing

World Health Organization. 2012. Definition, Diagnosis and Classification of Diabetes Mellitus and its Complications. WHO 